https://ejournal.uniska-kediri.ac.id/index.php/PROFICIENCY

\title{
THE EFFECT OF CONFIDENCE TOWARD \\ SPEAKING PERFORMANCE OF SPEAKING STUDENTS OF \\ SMART ILC PARE, KEDIRI
}

\author{
By: Fildzah Syarafina Nur Fajria
}

\begin{abstract}
This research is aimed to know whether there is any positive and significant effect toward confidence and speaking performance of speaking students of Smart ILC or not. Descriptive quantitative method was used as the approach to design this research. The instrument used was questionnaires and test. The result was the positive and significant effect toward confidence and speaking performance of speaking students of Smart ILC is rejected. It means there is no significant effect toward confidence and speaking performance of speaking students of Smart ILC.
\end{abstract}

Key words: effect, confidence, speaking performance

\section{INTRODUCTION}

Speaking is one of core components in English language proficiency which is highly important to be acquired by students. To acquire this skill, students need a special ability rather than only mastering a language in terms of grammatical terms or semantic rules. The students need to collaborate those two important items and how to use the language based on context of situation where the language is used (Mahripah, 2014). Smart's speaking program has different goal in every step of program. It starts from Speaking until tertiary speaking. In every Speaking Program has 2 meetings a day, and the total has 48 meetings in 1 month, every 10th and 25th period every month.

The result of learning speaking at Smart ILC for Speaking student can be seen from the increasing of student's capability by test examination of speaking and gets recommendation based on their improvement to continue for the next level of speaking program from teacher or not. Somebody who does not have a minimal score, 71-86, to pass to the next level, secondary speaking, they must join Placement Test. The Placement Test of Secondary speaking as the next level after Speaking is divided by two parts. The first is written test and the second is oral test. The material of oral test is Table Topic Session with daily activity theme of the question.

There are two main functions of the Placement Test for Smart ILC that is as a measurement of the ability of learners to get the target learners' learning responsibilities are always maintained and the second as the main evaluation reference in the measurement of methods and learning systems applied by the institution to maintain the area of responsibility of the institution on the 
https://ejournal.uniska-kediri.ac.id/index.php/PROFICIENCY

initial commitment and the competencies of output generated by the institution.

Speaking is not merely opening mouth and say words and sentences, but it includes a cultural background of a target language which is spoken to get meaningful interaction (McKay, 2008). Furthermore, speaking is one of productive skills where this aspect becomes a parameter of successful teaching and learning in classroom (Richard, 2008). Therefore, the students need to fight so hard to have a fluent speaking. However, many teachers have tried to apply various activities to have their students practice their speaking such as group presentation, peer friends conversation, and also debate by raising a certain issue (Hidayat \& Herawati, 2012).

Knowing above facts on how a language is used orally by a certain person, it is true that producing a good speaking performance in English is not easy for EFL students. In addition, acquiring English speaking is not as easy as first language especially for Indonesian students where English is a foreign language for them. It is very challenging for the students since it needs a great attempt because of its regularly present in the real life in everyday communication (Fauzan, 2016). It is a fact that English becomes one of compulsory subjects taught in Indonesia from elementary to university levels where it indicates that Indonesian students have studied English for many years. Based on this phenomenon, it is very interesting to highlight why Indonesian students still regard as low achievers in spoken English. Difficulty of EFL students on performing English speaking probably caused by cognitive or psychological factors. However, if the students with a good cognitive ability still have a difficulty on speaking, main psychological factors as motivation, self-esteem, and anxiety are potential aspects in influencing the students' oral performance (Aouatef, 2015). Particularly, there are the feeling of being afraid in making mistakes, lack of confidence and motivation, shyness, and also anxiety which exist when the students have to speak in front of the class (Juhana, 2012).

Furthermore, many experts point out that psychological factors give the most negative influence to the students' speaking activities (Bourezzane, 2014). Not only presents the negative influence, the psychological factors can make the students' English speaking performance difficult (Haidara, 2014). As an example, Putri (2014) has conducted a research on the correlation between anxiety as one of the psychological factors and students' speaking performance. As a result, there is a significant positive correlation between low anxiety score got by the students and their speaking performance and significant negative correlation between the students who got high anxiety score and their speaking performance. In other words, psychological factors are potential to affect the students' oral performance in negative ways. In this research, the researcher is 
https://ejournal.uniska-kediri.ac.id/index.php/PROFICIENCY

interested in investigating the psychological factors which affect the students' oral performance and which psychological factor hinders the students from speaking.

\section{RESEARCH METHOD}

The descriptive quantitative design was used as the approach of this research. It means that the result of this research has to be explained descriptively. The data needs to be analyzed by using quantitative because it is related to the formula and number. It was used to calculate the effect of confidence as variable $\mathrm{X}$ and speaking performance as variable Y.

To get the data, subject was taken in this research. The sample was the primary speaking in 10 April 2018 period. There are 4 classes there. The reason why the researcher took those was because those classes are taught by same English teacher.

Questionnaire and speaking test are given to the students as subject. The questionnaire is amounted 20 numbers. It contained the personality of each student about self-confidence and the test is about Table Topic Session in daily activity. The researcher conducted the research in 4 days for 4 classes.

\section{RESULT AND DISCUSSION}

After got the data, the researcher calculated it statistically used SPSS software. And these are the results. These results are explained below:

The table below shows us the descriptive statistic of the data. It contains mean, median, modus, deviation standard, standard error, range, maximum and minimum value and percentiles.

\section{Table 1. Descriptive Statistic of Both Variables}

\begin{tabular}{|c|c|c|c|}
\hline & & $\mathrm{X}$ & $\mathrm{Y}$ \\
\hline \multirow[t]{2}{*}{$\mathrm{N}$} & Valid & 64 & 64 \\
\hline & Missing & 0 & 0 \\
\hline \multicolumn{2}{|c|}{ Mean } & 45,86 & 14,95 \\
\hline \multicolumn{2}{|c|}{ Std. Error of Mean } & ,444 & 690 \\
\hline \multicolumn{2}{|c|}{ Median } & 45,00 & 14,50 \\
\hline \multicolumn{2}{|c|}{ Mode } & 45 & 12 \\
\hline \multicolumn{2}{|c|}{ Std. Deviation } & 3,550 & 5,522 \\
\hline \multicolumn{2}{|c|}{ Variance } & 12,599 & 30,490 \\
\hline \multicolumn{2}{|c|}{ Range } & 12 & 18 \\
\hline \multicolumn{2}{|c|}{ Minimum } & 40 & 6 \\
\hline \multicolumn{2}{|c|}{ Maximum } & 52 & 24 \\
\hline \multicolumn{2}{|c|}{ Sum } & 2935 & 957 \\
\hline
\end{tabular}

From table above, it could be seen that the mean of variable $X(C)$ was 45,86 and mean of variable $Y$ (SP) was 14,95. While median of those variables were 45.00 and 14.50. Modes of both variables were 45 and 12. Then $\mathrm{SD}_{\mathrm{x}}$ was 3,550 and $\mathrm{SD}_{\mathrm{y}}$ was 5,522. Then, the table showed the minimum and maximum scores of variable $X$ was $40 \& 52$ and variable $Y$ was $6 \& 24$. The descriptive statistic computation above was also used to compute the inferential statistic in this research, namely correlation. After knowing the descriptive statistic of the variable, it is served the categorization of each variable. 
https://ejournal.uniska-kediri.ac.id/index.php/PROFICIENCY

\section{Confidence}

Table 2.

Categorization of variable $\mathrm{X}(\mathrm{C})$

\begin{tabular}{|c|c|c|c|c|}
\hline No. & Value & Category & $\mathbf{F}$ & Percentage \\
\hline 1. & 10.4 & Very Bad & 0 & $0 \%$ \\
\hline 2. & $1.4-20.8$ & $\mathrm{Bad}$ & 0 & $0 \%$ \\
\hline 3. & $1.8-31.2$ & Enough & 0 & $0 \%$ \\
\hline 4. & $2.2-41.6$ & Good & 8 & $12.5 \%$ \\
\hline 5. & $2.6-52$ & Very Good & 56 & $87.5 \%$ \\
\hline \multicolumn{3}{|c|}{ Total } & 64 & $100 \%$ \\
\hline
\end{tabular}

From the table we can see that there are 56 students who thought that the confidence had a very good way in speaking performance, 8 students thought that the confidence had good way in speaking performance. There was no students thought that the confidence had bad and very bad way in speaking performance.

From the explanation above, the researcher concluded most of students thought that their confidence had very good way in speaking performance. It was proven with the number of frequency 56

\section{Speaking Performance}

Then, after serving the table of $\mathrm{X}$ variable, there is served categorization of variable $\mathrm{Y}$. The table shows about motivation among the second year students of MAN 3 Kediri. It can be seen that 36 students have very high motivation, 107 students are in high motivation, 3 students have enough/average motivation, and there is no student that has low and very low motivation. The table is served below:
Table 3.

Categorization of variable $Y$ (SP)

\begin{tabular}{|c|c|c|c|c|}
\hline No. & Value & Category & $\mathbf{F}$ & Percentage \\
\hline 1. & $0-4.8$ & Very Bad & 0 & $0 \%$ \\
\hline 2. & $5.8-9.6$ & $\mathrm{Bad}$ & 13 & $20.4 \%$ \\
\hline 3. & $10.6-14.4$ & Enough & 19 & $29.7 \%$ \\
\hline 4. & $15.4-19.2$ & Good & 14 & $21.9 \%$ \\
\hline 5. & $20.2-24$ & Very Good & 18 & $28.2 \%$ \\
\hline \multicolumn{3}{|c|}{ Total } & 64 & $100 \%$ \\
\hline
\end{tabular}

The table above showed about the speaking performance among the 10 April 2018 period of speaking students of Smart ILC. It can be seen that 18 students had very high ability in speaking performance, 14 students were in high speaking performance, 19 students had enough/average speaking performance, 13 students had low speaking performance, and 0 students had very low speaking performance. Most of students here had high motivation with the number of frequency 64 . It meant that most of the 10 April 2018 period of speaking students of Smart ILC had high speaking performance in speaking English.

\section{The effect of confidence toward speaking performance}

Then, there is the table of correlation value of variable $X$ and $Y$. The correlation is shown below.

Table 4. Correlation Value

\begin{tabular}{|cl|c|c|}
\hline & & $\mathrm{X}$ & $\mathrm{Y}$ \\
\hline \multirow{2}{*}{ C } & Pearson Correlation & 1 &,- 070 \\
& Sig. (2-tailed) & &, 583 \\
& N & 64 & 64 \\
& Pearson Correlation &,- 070 & 1 \\
SP & Sig. (2-tailed) &, 583 & \\
& N & 64 & 64 \\
\hline
\end{tabular}


https://ejournal.uniska-kediri.ac.id/index.php/PROFICIENCY

It shows about the correlation between two variables, namely confidence and speaking performance. The table contained number of correlation, number of cases, and significance level. Correlation used here was Pearson correlation with the value $-0,070$. The significance level is 2 tailed. It meant that the level significance is in the 0,01 or $1 \%$.

According to this value, it clearly could be seen that there was negative significant correlation between two variables being researched.

Regarding on the statement stated in the first chapter, the objectives of this research were to find out whether there was significant effect of confidence toward speaking performance of the Speaking students of Smart ILC and proved the hypothesis of this research. So, the researcher tried to find the answer. The explanation was in the statement below.

There are two kinds of hypotheses stated in this research. They were alternative hypothesis stated that there was significant effect of confidence toward speaking performance of the Speaking students of Smart ILC. Then the Null hypothesis stated that there wass no significant effect between confidences toward speaking performance of the Speaking students of Smart ILC.

Based on those two hypotheses, null hypothesis was chosen. Then, it was proven by the computation of correlation in table 4.4. As stated at the table, number of correlation is $-0,070$.Correlation value was higher than r.table at either
$5 \%$ or $1 \%$ level $\quad(0,159<-$ $0.070>0,210)$. It meant that the correlation is negative and significant. So, the alternative hypothesis was rejected.

The statement is not related with the research of Nguyen (2015) telling about Factors Affecting Students' Speaking Performance at Le Thanh Hien. In that research stated the results indicated that there were a variety of factors that affect the students' speaking performance. A majority of the teachers said that the students' speaking performance was affected by topical knowledge. Besides, the teachers' feedback during speaking activities also was also reported to affect the students' speaking performance. Finally, confidence was considered to be a factor that had influence on students' performance. In that research the subject of the study has a bad in spoken English. It was opposite with the speaking students of Smart ILC, that they have a good confidence to deliver their speech through table topic session question.

\section{CONCLUSIONS RECOMMENDATION}

AND

The conclusions of this research are (1) the confidence belongs to "good" category, it has mean 45,86. The standard of deviation is 3,550 . The highest score is 52 and the lowest is 40, (2) the speaking performance of speaking students of Smart ILC, Pare, Kediri. There are 18 students who belong to the "very high" category based on the table of categorization. Mean of speaking performance is 14,49 . And the standard deviation is 5,522, and (3) it shows that the " $r$ " score on 
https://ejournal.uniska-kediri.ac.id/index.php/PROFICIENCY

computation is $-0,070$. By looking at the table of SPSS, the "rxy" value is valid and significant at 2 tailed. It means that there is no correlation between confidence and speaking performance.

After knew the correlation, it can be concluded that speaking performance was not influenced by the confidence. So, there are some suggestions for the teacher. Those are (1) this research hopefully can give the knowledge to evaluate and also has awareness to evaluate objectively in order to increase students speaking performance. (2) the teacher is able to use the type of speaking performance in the right time. (3) the teacher should give more time when give the duty about speaking to the students, it can help them to add the vocabulary of theirs. For the students: (1) they can increase their spoken English by the way stay in English environment to improve their ability in speaking skill also can combine their good confidence to make good spoken English. For the further researcher: (1) to give a video performance of the students who deliver their speech, it is recommended to be source to conduct the next research.

\section{REFERENCES}

Brown, H.D. (2001). Teaching by Principles. An Interactive Approach to Language Pedagogy. Englewood Cliffs: Prentice Hall.

De Jong, N., \& Perfetti, C. A. (2011). Fluency training in the ESL classroom: An experimental study of fluency development and proceduralization. Language Learning, 1-36.

Elia, Fitra \& Irianti, Dewi. (2015). Psychological Factors that Hinder Students from Speaking in English. J-SHMIC Vol. 2 No. 4.

Heide, Adelide. (1979). The Relationship Between SelfEsteem and the Oral Production of a Second Language. Doctoral
Dissertation, University of Michigan.

Juhana. (2012). Psychological Factors That Hinders Students from Speaking in English Class (A Case Study in a Senior High School in South Tangerang, Banten, Indonesia). Journal of Education and Practice Vol. 3 No. 12. ISSN 2222-1735.

Kachru. Y \& Smith L. E (2008). Cultures, Contexts, and world Englishes. New York: Taylor $\&$ Francis.

McKay, P. (2008). Assessing Young Language Learners. Cambridge: Cambridge University Press.

Nunan, D. (1999). Second Language Teaching \& Learning. USA. Heinle \& Heinle Publisher. 